Article

\title{
Residential Tourism and Multiple Mobilities: Local Citizenship and Community Fragmentation in Costa Rica
}

\section{Femke van Noorloos}

Utrecht University, PO Box 80.115, 3508 TC Utrecht, The Netherlands;

E-Mail: h.j.vannoorloos@uu.nl; Tel.: +31-30-253-1363; Fax: +31-30-253-2037

Received: 8 January 2013; in revised form: 21 January 2013 / Accepted: 28 January 2013 /

Published: 4 February 2013

\begin{abstract}
Current patterns of "move-in move-out" hypermobility are perfectly exemplified by residential tourism: the temporary or permanent mobility of relatively well-to-do citizens from mostly western countries to a variety of tourist destinations, where they buy property. The mobility of residential tourists does not stand alone, but has broader chain effects: it converts local destinations into transnational spaces, leading to a highly differentiated and segmented population landscape. In this article, residential tourism's implications in terms of local society in Guanacaste, Costa Rica, are examined, starting from the idea that these implications should be viewed as complex and traveling in time and space. Mobile groups, such as residential tourists, can have an important local participation and involvement (independently of national citizenship), although recent flows of migrants settle more into compatriot social networks. The fact that various migrant populations continually travel back and forth and do not envision a future in the area may restrict their opportunities and willingness for local involvement. Transnational involvement in itself is not a problem and can be successfully combined with high local involvement; however, the great level of fragmentation, mobility, temporariness and absenteeism in Guanacaste circumscribes successful community organizing. Still, the social system has not completely dissolved.
\end{abstract}

Keywords: residential tourism; lifestyle mobilities; migration; citizenship; community involvement; participation; fragmentation; globalization; transnationalism 


\section{Introduction}

Current patterns of "move-in move-out" hypermobility are perfectly exemplified by residential tourism: the temporary or permanent mobility of relatively well-to-do citizens from mostly western countries to a variety of tourist destinations, where they buy (or sometimes rent) property. This mobility is driven by the search for a better way of life, a lower cost of living, etc. [1]. Indeed, tourism in many areas in the South is now deeply intertwined with real estate investment and urbanization: people buy property in the tourist destinations and stay there for shorter or longer periods. In recent years, the flow of residential tourists to developing countries (not the least of which is in Latin America) has become more prominent. While the phenomenon is difficult to quantify, general tourism numbers give an indication: international tourist arrivals increased by 43 percent between 2000 and 2011 (particularly in emerging economies), to reach 983 million worldwide [2]. If only $0.5 \%$ of these arrivals were residential tourists, their number would amount to nearly five million worldwide [3]. Residential tourism is a well-known phenomenon in destinations, such as Spain, Mexico and the Caribbean; more recently, this development has spread to wider areas in the South, for example, to Central America (Costa Rica, Nicaragua, Panama, Honduras), South America (Chile, Uruguay, Ecuador, Argentina, Brazil), South Africa, Turkey and Thailand.

Residential tourism is ambiguous and difficult to grasp: it is a mix of permanent and temporary mobilities, forming a bridge between tourism and migration and between nomadism and sedentarism. This makes it an interesting expression of current processes of mobility and globalization. In addition, residential tourism spawns a number of further migration flows (e.g., labor migration), causing a highly differentiated and segmented population landscape. These multiple human mobility flows in turn spawn an associated range of financial, material and cultural linkages [4]. Residential tourism, therefore, offers an opportunity to examine globalization and development chains and corridors [5] "on the ground".

A detailed understanding of current processes of mobility and globalization is provided by the literature on transnational migration. Since the 1990s, research on migration has paid much attention to transnationalism: the ways in which migrants' lives are affected by sustained connections with people and institutions in the places of origin [6-13]. Migrants are no longer seen as making a single move and integrating into the new context; rather, they construct multiple relationships in two places simultaneously. The case of residential tourism provides an interesting opportunity to turn around the debate on transnational migration: residential tourists are privileged with regard to income, social and cultural status, etc., compared to the local population. Various authors have argued that residential tourism offers good conditions for sustained transnationalism and "transnational settlement" into compatriot social networks (forming separate enclaves), rather than local incorporation [14-18]: according to Gustafson [14], retirees usually do not work in the host country; there are successive cohorts of ever new retirees; their motivations for moving are leisure-related; and they often attempt to maximize the amenities of both places (e.g., the weather) and move back and forth regularly. Regular travelling back and forth and maximizing amenities are proof of real transnational and mobile lives. Such behavior reflects these migrants' privileged position: their economic resources contribute to transnationalism. Similarly, Lizárraga Morales [18] mentions five reasons for the continued importance of transnational practices of US residential tourists in Mexico: economic access to 
advanced communications technologies; retirees have time and money to undertake return trips; Mexico's flexible migration policies; dependence on pensions as the main source of income spurs political participation (U.S. government decisions can directly affect retiree's finances); and children still live in the USA. These U.S. migrants were not only involved in tight social networks of compatriots, but also exercised active political transnationalism [18].

For Costa Rica, Puga [16] also mentions that "successful" local integration of retirees in the central valley does not mean social relations with the local populations, but rather satisfactory access to local services and interaction within the migrant community. Even after living there for a long time, retirees often live in a symbolic enclave, are involved in compatriot social networks and organizations and "consume" their place visually. McWatters [17] also noted residential tourists' patterns of intra-community socialization and their isolation from the native community in Boquete, Panama. In addition, he observed how residential tourists' relationship with Boquete is unsustainable and precarious: if it were to become overdeveloped, people would migrate elsewhere in search of a new paradise; thus, they show signs of "landscape nomadism" [17]. Indeed, according to Bauman [19], with the end of geography and the disappearance of distance, there is no longer a need for local social cohesion. Progressive spatial segregation, separation and exclusion are then consequences of globalization: there is a breakdown of communication between the global elites and the local rest [19]. As such, meaning is taken away from localities and place, and home becomes more insecure, exchangeable and transitory [20].

However, O'Reilly [15] showed that British residential tourists in Spain are not just highly mobile elites: a large group of British live in a rather disadvantaged position, unable to successfully integrate, but also unable to move back to Britain frequently and lead truly transnational lives. It is then important to give a more nuanced view of these types of mobility. Indeed, residential tourists are not only "transnationals" living in enclaves: various authors have highlighted the high socio-political involvement of various groups of lifestyle migrants or residential tourists in their local destination areas [21-25]. In addition, they engage extensively in volunteering and charitable giving [26]. As highly educated and environmentally conscious residents, who often migrate for reasons of tranquility, they can be important agents of change and political opposition to large-scale tourism or residential development [21]. Informal channels seem to be the main avenues for such political action. As such, despite the common view of lifestyle migrants as individualistic and apathetic, there has been successful political mobilization among them, both in collaboration with local groups and by themselves [22,25]. In this sense they can be viewed as "translocals": rather than claiming national citizenship rights, they attempt to exercise citizenship in their local destinations. Indeed, Smith and Guarnizo [27] argue that there has been a devolution of citizenship claims-making from the national to urban space: since a growing proportion of migrants lacks national citizenship and effective inclusion, representation and participation, they make their claims increasingly at the local level. For example, the debate on the "right to the city" [28,29] focuses on the right of city dwellers (including migrants) to participate in decision making processes that affect the quality of city life; and the right to appropriate and use urban space ([27], see also [30]). Thus, inhabitance of place becomes a basic prerequisite of citizenship.

In this article, I examine residential tourism's implications in terms of local society in one of Latin America's main residential tourism destinations: the northwest coast of Costa Rica (Guanacaste). 
I depart from the idea that these implications should be viewed as complex and travelling in time and space, forming development corridors and chains [3-5]. In Guanacaste, not only is there an influx of residential tourists, but the sector of residential tourism also attracts other groups of migrants, particularly Nicaraguan and domestic labor migrants. What does the coming together of highly divergent and mobile groups mean for local society? Can we still speak of locality, or is locality dissolved? I focus on various dimensions of citizenship, participation in local place-making and transnational involvement; particularly among residential tourists, but also among other migrants. Residential tourists turn out to be a diverse group, not just a highly mobile elite; and they do engage in place making. The fact that different groups act increasingly in separation and isolation, but especially the increase in people who consider their home in Guanacaste as exchangeable and transitory, is a threat to an integrated local system. However, there are still elements holding the place together.

\section{Methodology}

This article is mainly based on extensive survey-interviews among residential tourists in Guanacaste. In March-May 2011, 54 respondents approached in person in the coastal area between Flamingo and Pinilla participated in the survey, which focused on residential tourists' household and economic characteristics, property holdings, characteristics of their mobility to and from Costa Rica, motivations for moving, expenditure patterns and local and transnational involvement. In addition, an online version was completed by seven more residential tourists, bringing the total to 61 . The sampling was a combination of opportunity sampling and cluster sampling. Given the lack of data available on residential tourists, the technique was to select and visit a number of neighborhoods with high concentrations of residential tourists and knock on each door (then repeating this procedure once). We mostly found only about one third or less of the houses occupied. Within the small group of people we found at home, the response rate was high: about $85 \%$. We entered every residential tourism project possible in the area, which resulted in a very diverse range of residential tourism communities in different areas: from luxury to more mid-range and in different types of projects (land plot subdivisions, horizontal and vertical condominiums and all-inclusive gated communities). The range also included individual houses in open neighborhoods. Thus, the objective of wide representation was achieved.

In this article, residential tourists are divided into two groups: permanent residents (PRs: $\mathrm{N}=34$ ) and temporary residents (TRs: $\mathrm{N}=27$ ). Permanent residents or "lifestyle migrants" generally live in Guanacaste for more than 6 months a year and consider their property in Costa Rica their main home. Temporary residents visit Guanacaste repeatedly, mostly for shorter periods of time, for example, a few months per year or for repeated short holidays. They can be labeled as second home owners. Respondents were mostly from the U.S.A. (50\% PR, 70\% TR), followed by Canada and Europe. Genders are represented almost equally in the survey. Most residential tourists were couples without children (49\%), while 23\% were families with children (including singles with children). The remainder were singles living alone $(18 \%)$ or friends or other relatives living together $(10 \%)$. However, permanent residents were much more often families with children (35\% vs. $7 \%$ ). Retired couples were very common in the temporary resident category, with a mean age of 56 (49 for 
permanent residents). Most residential tourists owned their property in Costa Rica (62\% individual and 3\% timeshared ownership); 34\% rented.

Since triangulation and an inductive grounded theory approach were the main principles in the research, other methods this article loosely draws upon are semi-structured and open interviews (59 in total; mostly with other population groups in the area: Guanacastecans, domestic migrants and Nicaraguan migrants), participant observation (informal conversations and visits, participation in community meetings, etc.) and use of secondary data sources (national statistics, media sources, online blogs and discussions).

\section{Residential Tourists in Guanacaste}

Costa Rica has been a well-known relocation destination for North Americans for decades, but these migration flows have recently intensified and extended geographically to new coastal areas, which has made them much more concentrated and visible. Costa Rica's fame as an ecotourism destination has been complemented by the image of a country "for sale", a real estate frontier and relocation "paradise" for increasing groups of North Americans. Particularly in the mid to late 2000s, many coastal parts of the country underwent a rapid real estate boom, which was largely driven by international residential tourism. This research focuses on the northwest coastal region of Costa Rica (Guanacaste province), which has been the country's main area of real estate and residential tourism growth in the past decade (Figure 1). In the 2000s, Guanacaste changed from a small-scale tourism destination to an area of exponential large-scale and residential tourism growth, including real estate investment. From 2001 to 2006, the two main cantons in the research area (Santa Cruz and Carrillo) were among the main areas of construction growth in Costa Rica, which was mainly due to residential tourism: the area of new constructions in square meters increased exponentially (annually 159\% in Santa Cruz and 66\% in Carrillo) [31]. This high growth contrasts with steep declines during the worldwide economic crisis, particularly from 2008 onwards.

Figure 1. Research area: the coast of Guanacaste, Costa Rica.

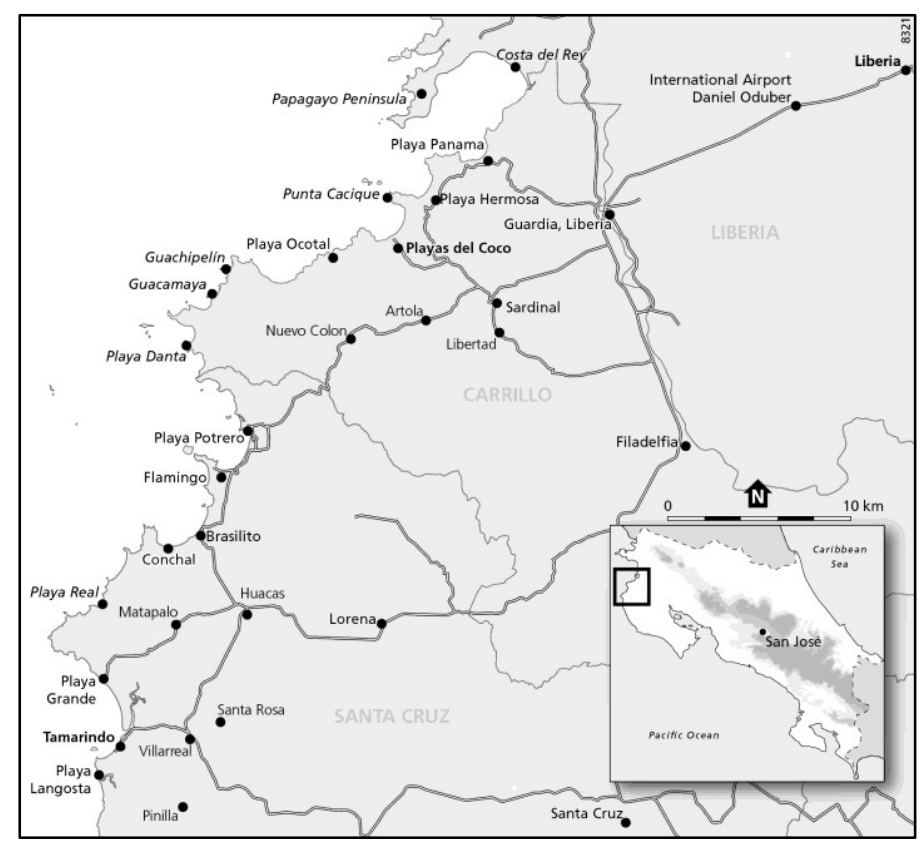


The flow of residential tourists to Guanacaste has not only intensified, but also diversified considerably in recent times. Many different groups of people are targeted: mostly from the U.S.A. and Canada, but also Costa Ricans from the Central Valley, from middle-income to elites and from permanent to temporary residents to short-term tourists. Individual house buying has made way for an extensive real estate sector, where most properties are bought within residential projects and urbanizations.

Estimates of the number of residential tourists in Guanacaste range from about $7 \%$ to $14 \%$ of the total population [3]. Based on airport exit questionnaires in Guanacaste [32,33], there were 2600-4800 foreign home owners visiting the research area $(6.6 \%-12.2 \%$ of the total population). Based on the housing stock [34] and average occupation, there were 2000 permanent residents (5\%) and 3400 temporary residents $(8.6 \%)$ in the research area. There is thus a high concentration of residential tourists in a small area. However, it is important to realize that permanent residential tourists are still a small group in Guanacaste. There is also much overlap between investment, tourism and residency: short-term tourists often end up buying property and, thus, become residential tourists (even though they keep coming to Costa Rica only for short holidays); property owners rent out their property to short-term tourists, so that many residential complexes are de facto hotels; shared ownership of properties is common (e.g., timeshares); and investors buy properties without one clear purpose (selling it, using it as a holiday home or using it later for retirement).

Residential tourists have a number of legal and irregular opportunities to migrate to Costa Rica. Despite the special pensionado/rentista visa, which has existed since 1964, residential tourism takes place partly independent of national migration policies: temporary residents stay on a tourist visa (which allows most western migrants to stay for up to 90 days), and many permanent western migrants do not acquire legal residency status, let alone national citizenship: many stay on a renewed tourist visa as "perpetual tourists". Regular pensionado/rentista migration procedures tend to be time-consuming: once all documents have been handed in, it can take 12-18 months before issuing [35]. The recent stricter migration rules have a potential to discourage people from applying for pensionado/rentista visas; this may increase irregularity and temporariness. Residential tourists' motivations for moving can be an important factor in explaining their local and transnational involvement. In order to grasp their motivations, respondents were asked in an open-ended question "Why did you decide to buy property and/or live in another country than your own?" The results were classified into categories and are shown in Figure 2 below. Reasons related to lifestyle and quality of life were the main reasons for residential tourists to leave their countries (21\%). Many of them mentioned a longing for coastal pura vida living, a relaxed lifestyle surrounded by nature and beach, a prolonged holiday, as directly opposed to their home country lives and retirements, which they portrayed as enduring work stress, personal stress and more - see also $[4,17,36]$. The lifestyle category is in this sense related to another category: the negative situation in the country of origin, for example, the political situation (unsatisfied with government, policies, taxes, etc.) and safety reasons (crime and natural disasters). These negative push factors account for only $9 \%$ in the survey, but the relationship between the pull factor "lifestyle" and the push factors is often strong. 
Figure 2. Residential tourists' motivations for moving. Source: author's survey.

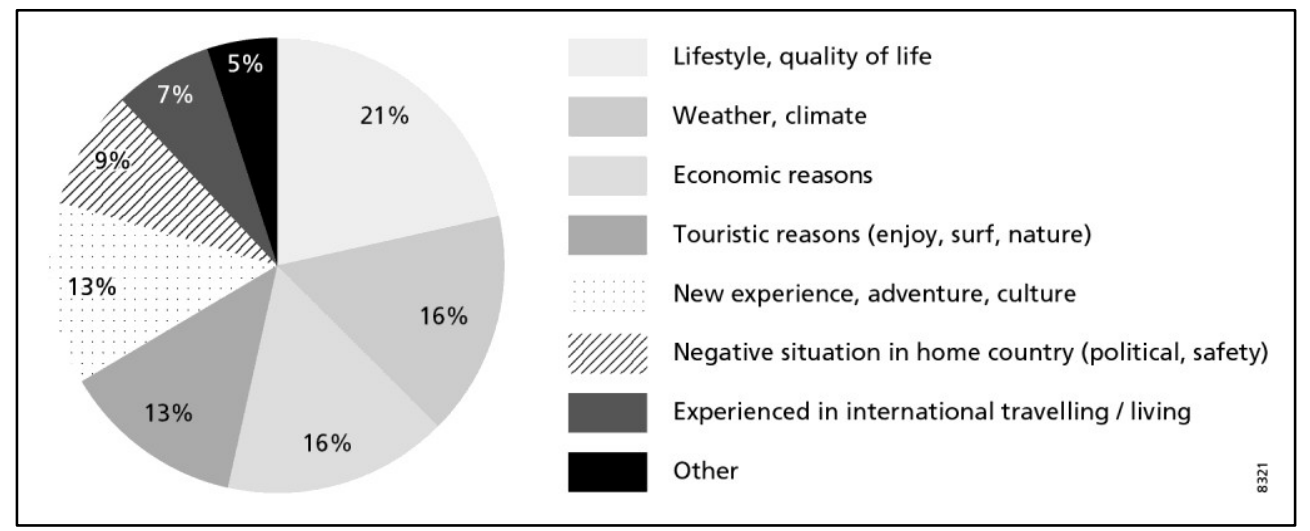

Another related category is the search for a new experience, a new adventure or a different culture, which $13 \%$ of respondents mentioned. The weather and climate were also mentioned specifically by $16 \%$ of the respondents as a reason to move. Furthermore, "touristic"/leisure reasons were mentioned by $13 \%$ of respondents: to enjoy a holiday, to surf or to enjoy nature. Economic reasons had made $16 \%$ move to or buy property outside their home country: the less expensive cost of living/housing in Costa Rica, but also economic opportunities, economic stability and a good investment. Another $7 \%$ found moving or buying property in another country a logical step, given their experience with travelling and living abroad.

Permanent residents (PRs) much more often mentioned reasons related to lifestyle and quality of life than temporary residents (TRs) (28\% PRs $v s .13 .5 \%$ TRs), and they were also more often driven by negative factors (political, safety) in the country of origin (13\% PRs vs. 3.5\% TRs). Temporary residents, on the other hand, were much more often attracted by touristic reasons (enjoyment, surfing, natural amenities): $20.5 \%$ TRs $v s .7 \%$ PRs. They also relatively often mentioned being experienced in international travelling and living in other countries as a reason (10\% TRs vs. 4\% PRs).

The reasons why residential tourists had chosen Costa Rica as a destination also reveal some interesting differences between the two groups. Permanent residents had relatively often chosen the country for its tranquility (the fact that it is not a mass tourism destination), the presence of family and friends already living there, health services and people, culture and language. Temporary residents had chosen Costa Rica relatively often for the beach, property prices and the availability of luxury housing and other amenities. Still, both groups were most interested in the weather/climate, relaxed lifestyle and the peaceful and democratic image of Costa Rica.

\section{Social and Economic Involvement}

Migrants' successful involvement in local society can be measured by their degree of social and economic involvement: economic activity, social contacts and informal networks with other groups present in the area, the ability to communicate in the local language and the use of local media.

Residential tourists are often regarded as economically inactive residents (i.e., retirement migrants) and, therefore, less able to integrate. Indeed, the most straightforward strategy for residential tourists in Costa Rica is to bring pensions or savings over from their country of origin and apply for a pensionado or rentista visa [37]; migration policies are most adapted to this type. If they aim to become 
economically involved as workers or business owners in Costa Rica, this is prohibited for most: residential tourists are seen as tourists, not as people who actively participate in the local economy. Participation in the formal labor market is difficult. Still, many of them have managed to circumvent these policies and work or own businesses (often irregularly) in Guanacaste. Indeed, residential tourists in Guanacaste are a broader group than just retirees: they are often younger and/or still involved in business or employment. When comparing permanent and temporary residents, the former more often owned their own businesses and mostly in Costa Rica (or in both countries) (30\%); see Table 1. Permanent residents also have possibilities to manage a business in the country of origin, while operating from Costa Rica (19\%; see Table 2), mostly through telecommuting, the stock market, Internet-managed businesses, etc., but also through frequent travel. A small proportion of permanent residents were employed (mostly in Costa Rica). Temporary residents were mostly retired (44\% as opposed to $33 \%$ for permanent residents); $19 \%$ owned businesses in the country of origin and $11 \%$ were employed there (Table 2). In general, those employed in the country of origin worked in highly skilled occupations in sectors, such as management, business, health and education.

Table 1. Residential tourists' local involvement in Guanacaste. Source: author's survey.

\begin{tabular}{lccc}
\hline Type of involvement & $\begin{array}{c}\text { Permanent } \\
\text { residents }\end{array}$ & $\begin{array}{c}\text { Temporary } \\
\text { residents }\end{array}$ & Total \\
\hline Employed in Costa Rica* & $8 \%$ & $2 \%$ & $6 \%$ \\
Own business in Costa Rica*** & $30 \%$ & $2 \%$ & $19 \%$ \\
Children at school in Costa Rica & $29 \%$ & $10 \%$ & $20 \%$ \\
Own home in Costa Rica & $68 \%$ & $65 \%$ & $67 \%$ \\
Health insurance in Costa Rica & $29 \%$ & $4 \%$ & $18 \%$ \\
Reads Costa Rican newspaper & $82 \%$ & $63 \%$ & $75 \%$ \\
Reads local town newspaper & $79 \%$ & $69 \%$ & $75 \%$ \\
Reads only English-language newspaper & $52 \%$ & $67 \%$ & $56 \%$ \\
Reads only Spanish-language newspaper & $35 \%$ & $22 \%$ & $31 \%$ \\
Classifies Spanish skills as bad or very bad & $33 \%$ & $67 \%$ & $48 \%$ \\
Classifies Spanish skills as good or very good & $37 \%$ & $17 \%$ & $28 \%$ \\
\hline \multicolumn{4}{c}{ Has most contact in Costa Rica with: } \\
Costa Ricans & $28 \%$ & $45 \%$ & $36 \%$ \\
Nicaraguans & 0 & 0 & 0 \\
People from country of origin & $50 \%$ & $35 \%$ & $44 \%$ \\
People from other countries & $24 \%$ & $30 \%$ & $27 \%$ \\
\hline respondents and their partners or second household members are taken into account (N = 109). \\
Respondents who had businesses both in Costa Rica and in the country of origin are also taken into \\
\hline
\end{tabular}

Of those who owned businesses in Costa Rica, surprisingly high numbers worked in tourism or real estate/property management (17\% and 50\%, respectively). From observations and interviews, it also became clear that many residential tourists combine a semi-retired life with self-employment in Costa Rica as real estate agents, property managers, tour guides, restaurant owners or advisors to new western migrants or by renting out their houses or rooms. Most of these types of businesses are fairly unregulated in Costa Rica (less subject to migratory control), and North Americans more than others 
have the networks and cultural knowledge to establish them. Hence, their economic involvement can be seen as a type of economic transnationalism [10].

Table 2. Residential tourists' involvement in country of origin. Source: author's survey.

\begin{tabular}{|c|c|c|c|}
\hline Type of involvement & $\begin{array}{l}\text { Permanent } \\
\text { residents }\end{array}$ & $\begin{array}{l}\text { Temporary } \\
\text { residents }\end{array}$ & Total \\
\hline Employed in country of origin* & $2 \%$ & $11 \%$ & $6 \%$ \\
\hline Own business in country of origin* ** & $19 \% * * *$ & $19 \%$ & $20 \%$ \\
\hline Children under 18 in country of origin & $7 \%$ & $5 \%$ & $6 \%$ \\
\hline Grandchildren in country of origin & $21 \%$ & $33 \%$ & $26 \%$ \\
\hline Parents in country of origin & $62 \%$ & $43 \%$ & $54 \%$ \\
\hline Own home in country of origin & $38 \%$ & $81 \%$ & $56 \%$ \\
\hline $\begin{array}{l}\text { Watches TV from country of } \\
\text { origin when in } \mathrm{CR}\end{array}$ & $71 \%$ & $81 \%$ & $75 \%$ \\
\hline $\begin{array}{l}\text { Voted during last national elections in } \\
\text { country of origin }\end{array}$ & $43 \%$ & $88 \%$ & $61 \%$ \\
\hline $\begin{array}{l}\text { Active member of political party in } \\
\text { country of origin }\end{array}$ & $23 \%$ & $47 \%$ & $33 \%$ \\
\hline $\begin{array}{l}\text { Median number of phone or chat calls to } \\
\text { country of origin per week }\end{array}$ & 7 & 7 & 7 \\
\hline Average number of return trips per year & 2.4 & $\mathrm{n} / \mathrm{a}$ & $\mathrm{n} / \mathrm{a}$ \\
\hline $\begin{array}{l}\text { Median } \mathrm{n}^{\circ} \text { of family and friends from in } \\
\text { country of origin who have visited } \\
\text { respondent in CR in past } 2 \text { years }\end{array}$ & 10 & 8 & 8.5 \\
\hline
\end{tabular}

Indeed, residential tourists in Guanacaste show a clear pattern of transnational settlement and integration into compatriot social networks. In the survey, respondents were asked to indicate with which groups they had most and least contact during their stay in Costa Rica. They were asked to rank four groups from 1 (most contact) to 4 (least contact): Costa Ricans, Nicaraguans, other people from their home country and other people from other countries (see Table 1). The respondents had most contact with people from their home country. These contacts were established in a variety of situations (asked for in an open-ended question): mostly as friends in social life, but also as neighbors, randomly meeting people at the pool, beach or supermarket or as workers and business clients. About the same situations are mentioned for "people from other countries" (mostly North America and Europe), who are ranked third. Costa Ricans are ranked second and mostly contacted as workers and friends/social, but also as neighbors and business clients. Nicaraguans were the group with whom these residential tourists had the least contact and mostly in their position as employees. Hence, while many residential tourists do have contacts with local Guanacastecans, field observations and interviews showed that many of them (particularly those from the USA) cling together in the same restaurants and bars (often run by North Americans, as well), form groups of friends, play golf, play cards together and organize dinner parties, reading clubs, book exchanges, charity events, etc. There are various churches for the 
foreign community. On the other hand, respondents also complained about living in such a gringo environment ("a bubble, a Costa Rican light", according to a survey respondent who lived in an all-inclusive gated community), the fact that many compatriots "want here to be like in the USA" and the difficulty of learning Spanish in such a situation.

Almost half of the respondents (excluding native Spanish speakers) classified their Spanish skills as bad or very bad (Table 1). However, for permanent residents, this is different: many of them considered their Spanish good or very good. Permanent residents also read more Spanish-language Costa Rican newspapers, though the majority of them read only English-language Costa Rican newspapers, which cater to the foreign community, such as the Tico Times and AM Costa Rica. There are also a number of bilingual and English-language local newspapers in various towns, which are important means in informing people and holding officials accountable. Besides the media, public space has been "foreignized" in important ways in parts of Guanacaste. Public space is filled with English-language publicity for real estate and tourism, and in towns like Tamarindo, English often seems to take over as the main language on the streets. Integration into gringo networks and services is relatively easy, since the short-term tourism sector in Guanacaste has long provided services and products from North America. Residential tourists' increased transnational settlement into compatriot networks can be explained by the larger size of the group, the introduction of gated communities and spatial segregation and the changing characteristics of residential tourists in Guanacaste (more often retired, different motivations). There has been a change from a more small-town open culture (including the first pioneer migrant groups), to a large town, with more group separation. One of the pioneer US settlers in Tamarindo explained:

The mentality of the people has changed a lot; now, there is a lot of exploitation of real estate. These real estate people have no idea of how it is here; the people who arrive now don't know how it was before and don't care about learning Spanish; they could be on any beach in the world. (....) Q: How have social relations changed? A: They have changed completely. (....) Now, when people are sick or dying, no one knows or does anything. Before, this was a small village; now, it's this international conglomerate. We used to have bingo parties on Saturday nights, because there was nothing else to do. Now, you see only gringos at those bingo parties; before, everyone went: ticos, gringos. Q: Are ticos and gringos becoming more distant, then? A: I don't know. There are very few ticos left [38].

\section{Socio-Political Involvement}

Migrants generally lack formal decision-making power and opportunities to influence political processes in their localities and at the national level. After seven years of living legally in Costa Rica, migrants may apply for Costa Rican citizenship, which very few foreign residents do. Still, it is the only way to obtain voting rights or other formal political positions. The prohibition of formal political participation by foreigners can have clearly visible consequences for local politics; for example, many North American expats in Tamarindo would like to see Tamarindo become a separate municipality, as they feel ignored by the Santa Cruz municipality [25]. However, few Costa Rican citizens living in Tamarindo favor this municipal division, and expats cannot muster enough votes to achieve such a division [25]. In fact, in-depth interviews show that residential tourists consider themselves quite 
powerless in Guanacaste: their image of national and local political institutions is as very powerful, and their lack of trust in this political field and lack of formal abilities to influence it, lead to feelings of resignation and powerlessness [3,39].

However, to provide a complete picture, a focus beyond only formal political influence is useful. A distinction should be made here between three groups: tourism developers and investors, permanent residents and temporary residents. Direct formal or informal access to politics is mostly achieved by large-scale developers and investors, both international and from Costa Rica. As many residential projects are realized by a combination of Costa Rican and North American developers and capital and the national developers are often well-connected in politics, direct access to local and national government and politicians is guaranteed. In addition, tourism developers have an influence through their formal and informal lobbying networks.

In contrast to powerful developers, residential tourists generally do not have much direct informal influence in politics. They can influence their surroundings through civil society organizations and social action; the international community in Costa Rica is well-organized and highly visible [16]. In Guanacaste, permanent residential tourists are involved in a range of organizations. In my survey, 10 of the 34 permanent residents I spoke to were involved in organizations for infrastructure, services and environment: more specifically, eight of them were involved in a local town association for infrastructure, recycling, cleaning etc., one was involved in a community water and sewer association (ASADA) and one contributed to a local environmental organization. These data correspond with interviews, observation and Internet data on membership and different types of local associations in Guanacaste coastal area. During in-depth interviews [3,39], half of the respondents indicated being open to joining organizations or protests regarding their direct environment. Organizations in which these residents are involved are often neighborhood organizations that collectively arrange infrastructure and services, such as recycling, waste collection, beach cleaning, security, etc. Through these organizations, residents can claim services from local government or arrange their own services. This often happens in communities where many foreign residents are concentrated and English is the main language in these organizations. Those involved are often long-term residents and/or small tourism business owners. In addition, small tourism business owners (e.g. in Tamarindo) have established associations because of their need for infrastructural improvements in order to cope with the growing tourist sector, which local government could not provide. A few residential tourists are also involved in more activist environmental organizations that influence public opinion through protests and file judicial complaints. However, interviews showed that influence of residential tourists through protest and judicial action is not very common, as gringos tend to be cautious about these more controversial types of involvement: local people can be highly suspicious of "foreign-led" organizations.

Hence, permanent residential tourists are widely involved in organizations, with a number of very active members. Western residents have traditionally organized themselves separately from the local population in Guanacaste, possibly because of the low degree of local organization in the area, but also because of spatial segregation and diverging goals. Despite the segregated nature of their participation, residential tourists' involvement in Guanacaste is often effective: their organizations can exert power and build connections with local government. This is because of, for example, the long-term establishment of a foreign community there, which has managed to build up social capital. Observation 
and interviews showed that there is still a group of residents that are very locally involved: they are often long-term residents who form a bridge between new residential tourists and the local population, contributing to a more multi-ethnic society and positive views of other groups. In addition, the relatively high status and economic, social and cultural capital of residential tourists are important explanatory factors for their incorporation. Not only do they bring in significant amounts of money compared to Costa Rican salaries, but residential tourists also have high levels of education (79\% have finished college or higher) and have often had (or still have) high-level jobs. Some of them have owned businesses. These migrants are used to having an influence and being heard and have the ability to do so. This makes for an actively involved group of concerned citizens.

On the other hand, various forces work against residential tourists' effective local involvement, such as their lack of Spanish skills and cultural-institutional knowledge and their position as outsiders and only partial acceptance by the local community. However, possibly the greatest limitation is temporariness and absenteeism. Indeed, residential tourists who visit the area for a few months per year or less (temporary residents) are hardly involved in local organizations, except for home owners associations. As such, the temporary residential tourists and absentee home owners hardly participate in local social organizing. The temporariness of residents also leads to a lack of stability. The community organization landscape in Guanacaste is much dispersed and somewhat unstable: many small committees are active, they can easily disappear or appear again, also depending on very unstable and changing contributions from community members. In addition, as one survey respondent indicated, maintaining a decent level of collective services is not easy in Guanacaste, with many temporary residents, absentee homeowners and the economic crisis:

Many other home owners in this project have gone back to their home countries and sold their houses. There are almost no home owners left now, only renters. There are many absentee landlords who only come for short times; they won't pay for the maintenance etc. It is difficult to build a community like this; this is a problem [40].

A Costa Rican business owner also had the experience that because of the economic crisis, in many small condominium projects in Playas del Coco, "the problem is that people no longer even want to pay to have the pool maintained and things like that." Many residential tourists' touristic motivations and leisure-oriented outlook on local place do not encourage local involvement either.

\section{Transnational Involvement}

Permanent residents often combine local incorporation in Costa Rica with significant transnational involvement in their country of origin, for example, through regular contacts and return trips. Temporary residents are highly mobile and more transnational in orientation, and they are generally less involved in local society.

As expected, both permanent and temporary residential tourists stated that they maintain close personal links with their country of origin. All, except one of the 46 respondents, had an Internet connection at home in Costa Rica. Respondents made a median of seven phone or chat calls per week to their country of origin (Table 2). Permanent residents were asked how often they return to their country of origin: the average number of return trips was 2.4 per year. Almost $70 \%$ went back at least 
once a year. Residential tourists regularly receive many friends and family members in Costa Rica (Table 2), contributing to their transnational lives there. Home ownership can also be an important sign of a transnational orientation: as many as $38 \%$ of the permanent residents still owned a home in their country of origin and $24 \%$ rented one (though not always for the whole year). For temporary residents, home ownership in the country of origin was $81 \%$, and some of them even owned a second home in the country of origin.

Politically, respondents were also still quite involved in their home country in terms of voting (61\% had voted during the last national elections) and being registered or members of a party (33\%). When asked if they had been involved in home country politics in any other way while being in Costa Rica in the previous five years, only $12 \%$ mentioned some type of involvement: discussing with friends (online or in real life), donating money, etc. These were mostly permanent residents.

It is often argued that migrants' continued transnational involvement in the country of origin may circumscribe their local involvement. In order to investigate the relationships between transnational and local involvement for residential tourists, I built three indexes from survey data, based on various variables: a local involvement index, a transnational socioeconomic involvement index and a transnational political involvement index [41]. There is a positive correlation between permanent residents' local social involvement in Costa Rica and their transnational political involvement in the country of origin (Pearson correlation, 0.575 ; sig 0.001 ). Hence, permanent residents clearly combine important local involvement with high transnational (especially political) involvement: in their case, transnational and local involvement are not contradictory at all. Temporary residents have a significant transnational involvement by "nature" of their more flexible and temporary status (the country of origin is their main place), but some of them do combine this with more local involvement in Costa Rica — no significant relationships were found.

In order to investigate which variables contribute to local involvement in Costa Rica and transnational involvement, I again used the three indexes. Independent samples $t$-tests for equality of means were carried out in SPSS Statistics software to compare mean scores of different groups on various variables and check for significant differences between them (Table 3). The difference between permanent residents and temporary residents is the only variable that clearly and independently makes a difference for local involvement [42]: permanent residents are clearly more involved in Costa Rica. Regarding transnational involvement, as might be expected, temporary residents are more socioeconomically and politically involved in the home country than permanent residents. In addition, the length of the periods of time spent in Costa Rica makes a difference for transnational involvement when we look only at permanent residents: the longer a respondent has been in Costa Rica (CR), the lesser their socioeconomic transnational involvement (Table 3).

The data suggest that the main explanatory variable for transnational and local involvement is the difference between temporary and permanent residents. This means that rather than looking at transnational involvement as such a barrier to local involvement, we should focus our attention on the more general temporariness, flexibility and absenteeism present among certain mobile groups, which arguably comprise a more serious barrier to local embeddedness. 
Table 3. Selected factors that explain local and transnational involvement of residential tourists in Guanacaste. Source: author's survey.

\begin{tabular}{ccc}
\hline Variable & Score differences & $\begin{array}{c}\text { Significance } \\
\text { (2-tailed) }\end{array}$ \\
\hline $\begin{array}{c}\text { Local involvement } \\
\text { Permanent (P) vs. } \\
\text { temporary residents (T) } \\
\text { Transnational } \\
\text { involvement }\end{array}$ & P 36.3; T 20.2 & 0.000 \\
$\begin{array}{c}\text { Permanent (P) vs. } \\
\text { temporary resident (T) } \\
\text { Time spent in Costa Rica } \\
\text { (only permanent } \\
\text { residents) }\end{array}$ & $\begin{array}{c}\text { Socioeconomic: P 4.6; T 5.8 } \\
\text { Political: P 1.5; T 2.4 }\end{array}$ & 0.050 \\
\hline
\end{tabular}

In the case of residential tourists, their temporariness and flexibility are interrelated with their touristic or lifestyle-related motivations for moving and with their high economic capital. Their lifestyle and amenity-related motivations for migration lead to a more flexible view of their migration: if the reasons for their migration (e.g., beautiful nature, safety) disappear, they can easily move on to other places ("landscape nomadism"; see McWatters [17]). Their relatively advantageous financial situation also allows them more liberty to move on or return to their country of origin. They are not obliged to adapt to local changes, which may lead to lower local involvement. In the survey, almost half of the respondents who owned their property in Costa Rica would consider selling it or were already doing so. Thus, home ownership is no longer a necessary indicator of local involvement: while home ownership is generally high among residential tourists in Guanacaste, this does not mean they have permanent strong bonds to the area. As we have seen, many regard their home in Guanacaste as a second home or an investment. Thus, property transfer is high and residential tourists have various mobility options; homes are exchangeable [20]. Indeed, $26 \%$ of respondents owned one or more other properties (not in the country of origin), often as an investment: mostly in Guanacaste, other areas of Costa Rica, one in Panama and one in Nicaragua. In in-depth interviews [3,39], 11 of the 16 respondents said they would leave and go elsewhere (e.g., Central America, South America) if Guanacaste changes too much. However, most did not think it would change too fast or soon become overdeveloped. The freedom to leave has also become more restricted since the economic crisis, as many foreigners could not sell their houses even if they wanted to. It is still unclear whether westerners' mobility towards Guanacaste will become more permanent or remain rather temporary.

\section{New Mobilities As a Chain Effect of Residential Tourism: Labor Migrants}

The industry of residential tourism has not only attracted a diverse array of residential tourists, but it has also given rise to chain effects and other migration flows [4]. Local society is also greatly influenced by these other (old and new) flows of people, which I briefly reflect upon here, drawing on observation, interview and national statistics data. 
In Guanacaste, both high-skilled and low-skilled labor migrants have been attracted in large numbers. Low-skilled labor migrants are mostly Nicaraguans, who work in construction, domestic work, private security and tourism. Nicaraguans make up $10.8 \%$ of the population in the research area [43]. High-skilled labor migrants in tourism, real estate, project developing, construction, etc. are partly western, but also many domestic migrants from the central valley (Greater Metropolitan AreaGAM). Domestic migrants make up $8.5 \%$ of the population in the research area [43], and the majority of them is from the GAM. Besides the highly-skilled, other people from the GAM came to the area as well, often in more self-organized ways: because of family ties, for low-skilled work or to establish small businesses. In addition, families that had migrated to other regions in earlier decades have returned to the area. There are other smaller groups in the area that are also related to the tourism/residential tourism industry, for example, Colombians, Venezuelans and Dominicans.

Many Nicaraguans in Guanacaste are long-term permanent migrants in a regular situation who have lived in the area for decades. However, a large number of temporary and irregular Nicaraguan migrants are also present, particularly those who work in construction-although in the research area, the number may have decreased since the economic crisis. Temporary and seasonal migration is common among Nicaraguans, and rural Nicaraguan families increasingly opt for livelihood strategies in which production takes place in Costa Rica, whereas reproduction is left in Nicaragua (as it is cheaper there) [44]. Nicaraguans are highly economically involved in various sectors, though often in disadvantaged ways. Nicaraguan migrants' social incorporation in Guanacaste is mainly into compatriot networks, followed by Costa Rican networks. Their compatriot networks are mostly more informal, for example, small churches and family and friendship bonds. On the other hand, compared to residential tourists, Nicaraguans are more involved in local society via labor, education, language and living in the same neighborhoods as Costa Ricans. Nicaraguan migrants' involvement in sociopolitical issues is very low, because of their livelihood orientation and low economic, social and cultural capital. This is even the case for more permanent and established migrants, whose economic situation is often still vulnerable. In some cases (particularly temporary migrants), transnational involvement may be a factor that explains their lack of social involvement in Costa Rica: because of their exclusive focus on employment in Costa Rica and earning money for remittances or investment, their time (and motivation) for local involvement is limited. However, temporariness, flexibility and a view towards returning to Nicaragua is a main factor in this, rather than transnational involvement as such. In fact, Nicaraguans' socio-political involvement in the country of origin is very low and their transnationalism consists mostly of economic and social bonds.

Domestic migration into Guanacaste has a long history, and traditionally, these migrants have assimilated into the local place: many of them were business and tourism pioneers and highly locally involved, although there is still social differentiation and some ethnic sensibilities. However, current new flows of domestic migrants are increasingly diverse; and particularly, the higher classes may have a lower local participation, as they are often spatially segregated into gated communities. In addition, highly skilled labor migrants often have a more temporary outlook on local residency and a view towards returning. Hence, labor migration flows, even if they have a longer history and are more integrated into local society, have also changed: Nicaraguan and domestic migrants are increasingly temporary, flexible and possibly less involved in local society. 


\section{Conclusions}

The literature on transnational migration has highlighted a number of factors, which influence migrants' integration into host society. Political opportunity and constraint structures have created opportunities for regular migration for both western and Nicaraguan migrants, but they have also caused large irregular flows of both groups. These irregular groups are treated as short-term and temporary; in the case of western migrants, they are seen as tourists, whereas Nicaraguans are regarded as seasonal workers. In general, this dualism and the subsequent classification of a large population as temporary and non-resident hinders their local involvement, for example, in political matters.

Economic and social capital can compensate for political limits. Residential tourists in Guanacaste can be highly involved and exert power on local place, because of their high status and economic, social and cultural capital. Particularly permanent and long-term residents have a broad informal participation in social organizations that attempt to influence local place. They become "trans-locals" in the sense that national citizenship is not necessary to be able to reach effective involvement and influence on local affairs: local citizenship partly replaces national citizenship [27]. The same high social and cultural capital and local involvement can be found among older groups of domestic migrants. On the contrary, Nicaraguan migrants, even the more long-term and permanent groups, exert little influence, because of their low economic capital and education, an exclusive commitment to economic participation and their low social status and discrimination in Costa Rican society. For them, national citizenship, however difficult it may be to acquire, does provide many advantages.

Despite the immigration of economically powerful groups, local Guanacastecans have various sources of power and opportunities; they can "reclaim" citizenship by establishing or joining organizations and protests and, somewhat, through formal politics. Guanacastecans can use their status as "original inhabitants" and their connections to and knowledge of national institutions to exert power and defend themselves from unwanted developments. They derive a certain amount of power from their sociological age or position as original inhabitants [45].

This brings us to some further limits to residential tourists' participation: they often prefer not to become too much involved in local issues, as "the ticos don't want us to be involved". Furthermore, residential tourists' involvement and power is limited by their low cultural capital in local society. Their social integration into local society in terms of social contacts and a profound understanding of local place is also limited by such factors. While there is still a group of permanent residents with often long-term involvement in the area and high social integration, many new residential tourists' social integration is limited. Recent developments have decreased possibilities for integration into other than compatriot groups: these include the larger number of residential tourists, their more explicit leisure motivations and increased spatial segregation into gated communities. All this makes it much easier for them to assimilate into compatriot communities rather than local networks. In sum, local society and the history/process of their migration prevent local social embeddedness, as other authors have also noted [14-18].

However, this lack of embeddedness is particularly salient among temporary residents, by nature of their continuous back-and-forth movements and living in two worlds. Thus, a major barrier to a cohesive local society seems to be this absenteeism, flexibility and temporariness of large populations. In the case of residential tourists, this is also related to their leisure motivations. Indeed, the main 
motivations for the moving of permanent residents (i.e., the search for a better way of life and negative push factors in the country of origin) make them more interested in actively influencing their surroundings [22]. In contrast, temporary residents more often move for touristic or leisure-related reasons, namely to enjoy a prolonged holiday on the coast. Amenity maximization leads these temporary residents to move back and forth regularly [14]. Thus, they may have fewer reasons to become involved in wider local society and a high inclination to incorporate into compatriot social life. Such leisure motivations also make them willing to switch to other places if the place changes too much: they may show signs of "landscape nomadism" [17]. This is further enhanced by temporary residential tourists' relatively advantageous financial situation, which allows them more liberty to move on or return to their country of origin. They are not obliged to adapt to local changes, which may lead to lower local involvement. The same is true for new groups of domestic migrants-highly-skilled people who stay in the area for short periods - but also Costa Rican residential tourists, who may stay in the area during weekends and holidays. Temporariness, flexibility, a continuing economic and social commitment to transnational households and a view towards returning to the country of origin are major factors in Nicaraguans' lack of local social involvement, as well.

Thus, with many mobile and temporary groups, it is more difficult to fight common urban quality of life problems. The fact that these mobile populations continually travel back and forth and do not envision a future in the area may restrict the opportunities and willingness for local involvement. Transnational involvement in itself is not a problem (it can be successfully combined with high local involvement [10,46]); however, the great level of fragmentation, mobility, temporariness and absenteeism in Guanacaste circumscribes successful community organizing.

Based on recent developments, it can be expected that the change from long-term residential tourists who are highly locally involved, to a new group of more segregated residents, will continue, with more all-inclusive developments and higher numbers of retired residential tourists. Tighter migration policy and the continued view of western residents as tourists are counterproductive and only add to this problem. The scenario of ever new groups of residential tourists coming in and older more embedded and environmentally-aware groups leaving the area to find a better place is possibly the worst case scenario for social cohesion and defense of the local place. Whereas many western residents are already considering leaving the area, the current crisis is probably slowing down such continuous movement (with the halting of new developments and their inability to sell their houses).

Is it true, then, that, as Bauman [19] asserts, people no longer perceive a need for local social cohesion under globalization - and the results are progressive spatial segregation, separation and exclusion. Bauman's view of a deep segregation between a hypermobile elite and a large poor "imprisoned" group [19] seems rather exaggerated: residential tourists are not only such a highly mobile elite (see also O'Reilly [15]), and they do engage in place making [21-23]. Labor migrants exert active agency to improve their lives, and local people are far from imprisoned: while they have seen their place changing rapidly, many people are highly mobile and increasingly active in attempting to change their place. Power differences and inequalities are an inherent characteristic of such a diversified, globalized place; however, residential tourists' power is far from unlimited, and local people can exert influence. The fact that these groups act increasingly in separation and isolation, but especially the increase in people who consider their home in Guanacaste as exchangeable and transitory [20], are indeed threats to an integrated local system. However, there are still elements 
holding the place together, and importantly, people live in a peaceful, accepted separation, without much outright hostility.

\section{Conflict of Interest}

The author declares no conflict of interest.

\section{References and Notes}

1. Other labels for such mobility are international retirement migration, lifestyle migration, amenity migration and second home development.

2. UNWTO (UN World Tourism Organization). UNWTO Tourism Highlights 2012 Edition; UNWTO: Madrid, Spain, 2012. Available online: http://www.unwto.org/facts/menu.html (accessed on 1 August 2012).

3. Van Noorloos, F. Whose place in the sun? Residential tourism and its implications for equitable and sustainable development in Guanacaste, Costa Rica. PhD Thesis, Universiteit Utrecht, Utrecht, the Netherlands, 2012.

4. Van Noorloos, F. A transnational networked space: Tracing residential tourism and its multi-local implications in Costa Rica. Int. Dev. Plann. Rev. 2011, 33, 429-444.

5. Zoomers, A.; van Westen, G. Introduction: Translocal development, development corridors and development chains. Int. Dev. Plann. Rev. 2011, 33, 377-388.

6. Schiller, N.G.; Basch, L.; Blanc, C.S. From immigrant to transmigrant: Theorizing transnational migration. Anthropol. Quart. 1995, 68, 48-63.

7. Kearney, M. The local and the global: The Anthropology of Globalization and Transnationalism. Annu. Rev. Anthropol. 1995, 24, 547-566.

8. Vertovec, S. Migration and other modes of transnationalism: towards conceptual cross-fertilization. Int. Migr. Rev. 2003, 37, 641-665.

9. Faist, T. Migrants as transnational development agents: An inquiry into the newest round of the migration-development nexus. Popul. Space Place. 2008, 14, 21-42.

10. Landolt, P. Salvadoran economic transnationalism: embedded strategies for household maintenance, immigrant incorporation, and entrepreneurial expansion. Global Netw. 2001, 1, 217-241.

11. Portes, A. Conclusion: Towards a new world-The origins and effects of transnational activities. Ethnic Racial Stud. 1999, 22, 463-477.

12. Portes, A.; Guarnizo, L.E.; Landolt, P. Introduction: Pitfalls and promise of an emergent research field. Ethnic Racial Stud. 1999, 22, 217-237.

13. Lazăr, A. Transnational migration studies. Reframing sociological imagination and research. Journal Comparative Research Anthropology Sociology 2011, 2, 69-83.

14. Gustafson, P. Transnationalism in retirement migration: the case of North European retirees in Spain. Ethnic Racial Stud. 2008, 31, 451-475.

15. O'Reilly, K. Intra-European migration and the mobility-enclosure dialectic. Sociology 2007, 41, 277-293. 
16. Puga, D. Un lugar en el sol: Inmigración de jubilados hacia Costa Rica. In Población del Istmo 2000: Familia, Migración, Violencia y Medio Ambiente, (in Spanish); Rosero-Bixby, L., Ed.; CCP: San José, Costa Rica, 2001; pp. 253-276.

17. McWatters, M.R. Residential tourism. (De)constructing paradise; Channel View: Bristol, UK, 2009.

18. Lizárraga Morales, O. Immigration and transnational practices of U.S. retirees in Mexico. A case study in Mazatlán, Sinaloa and Cabo San Lucas, Baja California Sur. Migración y Desarrollo 2008, 11, 93-110.

19. Bauman, Z. Globalization: The Human Consequences; Polity Press: Cambridge, UK, 1998.

20. McWatters, M.R., Ed.; Residential tourism: (De)constructing Paradise; Channel View: Bristol, UK, 2009; pp.48-49.

21. Janoschka, M. The contested spaces of lifestyle mobilities: regime analysis as a tool to study political claims in Latin American retirement destinations. Die Erde 2009, 140, 251-274.

22. Janoschka, M. Between mobility and mobilization-lifestyle migration and the practice of European identity in political struggles. Sociol. Rev. 2010, 58, 270-291.

23. Janoschka, M. Imaginarios del turismo residencial en Costa Rica. Negociaciones de Pertenencia y Apropiación Simbólica de Espacios y Lugares: Una Relación Conflictiva. In Construir una Nueva Vida. Los Espacios del Turismo y la Migración Residencial, (in Spanish); Mazón, T., Huete, R., Mantecón, A., Eds.; Milrazones: Santander, Spain, 2011; pp. 81-102.

24. Van Fossen, A.; Lafferty, G. Contrasting models of land use regulation: Community, government and tourism development. Community Dev. J. 2001, 36, 198-211.

25. Pera, J.L. Tamagringo: Citizenship and Community Change in Tamarindo, Costa Rica. MA Thesis, University of Oregon, Oregon, OR, USA, 2008.

26. Kiy, R.; McEnany, A. Civic Engagement, Volunteerism and Charitable Giving: Americans Retiring in Mexico's Coastal Communities. In U.S. Retirement in Mexico Research Series; International Community Foundation; National City, CA, USA, 2010.

27. Smith, M.P.; Guarnizo, L.E. Global mobility, shifting borders and urban citizenship. Tijdschr. Econ. Soc. Ge. 2009, 100, 610-622.

28. Lefebvre, H. Le Droit á la ville, (in French); Anthopos: Paris, France, 1968.

29. Marcuse, P. From critical urban theory to the right to the city. City 2009, 13, 185-197.

30. Gárriz Fernández, I. The Right to the City as a conceptual framework to study the impact of North-South migration. Recreation and Society in Africa Asia and Latin America 2011, 2, 3-33.

31. Instituto Nacional de Estadística y Censos Costa Rica-INEC: Construction statistics. Available online: http://www.inec.go.cr/Web/Home/GeneradorPagina.aspx (accessed on 2 January 2011).

32. Instituto Costarricense de Turismo (ICT) tourism statistics 2009-10. Available online: $\mathrm{http}: / /$ www.visitcostarica.com/ict/paginas/modEst/estudios_demanda_turistica.asp?ididioma=1 (accessed on 2 January 2011).

33. CATURGUA, 2008, in Román, M. Dinámica del mercado inmobiliario en la costa pacífica de Costa Rica. In The Impact of Tourism Related Development along Costa Rica's Pacific coast; (in Spanish) Center for Responsible Travel: Washington, DC, USA, 2009; p.29. Available online: http://www.responsibletravel.org/resources/Coastal-Tourism.html (accessed on 2 January 2011).

34. INEC census 2011: Preliminary data. Available online: http://www.inec.go.cr/Web/Home/ GeneradorPagina.aspx (accessed on 1 June 2012). 
35. Baxter-Neal, L. Incentives for Retirement \& Investment in Costa Rica. In The Impact of Tourism Related Development along Costa Rica's Pacific coast; Center for Responsible Travel: Washington, DC, USA, 2010. Available online: http://www.responsibletravel.org/resources/ Coastal-Tourism.html (accessed on 2 January 2011).

36. Benson, M.; O'Reilly, K. Migration and the search for a better way of life: A critical exploration of lifestyle migration. Sociol. Rev. 2009, 57, 608-625.

37. Since 2010 , for a pensionado residency a guaranteed monthly government or private pension of at least $\$ 1000$ per household is needed (compare: $\$ 600$ under the old law). For a rentista visa, the required amount is $\$ 2500$ per month of guaranteed income (formerly $\$ 1000$ ).

38. Interview US resident Tamarindo, 19 September 2008

39. Kool, J. Residential tourists in Guanacaste, Costa Rica - who are they, and what is their local involvement? MSc Thesis, Utrecht University, Utrecht, The Netherlands, 2012.

40. Respondent of survey residential tourists, 2011

41. The index for local involvement included use of Costa Rican media, activities in Costa Rica that increase involvement, such as volunteering, involvement in local organizations, contacts with Costa Ricans and Nicaraguans and Spanish skills. The transnational socioeconomic involvement index includes: work or business in the country of origin, number of return trips, number of phone or chat calls weekly and owning or renting a first and second home there. The transnational political involvement index means having voted in the last elections in the country of origin, being involved or a member of a political party or organization there and using home country media.

42. For example, having employment or business or having children at school in Costa Rica (which is much more common with permanent residents) makes a difference for local involvement, but not anymore when only permanent residents are taken into account. The time respondents have spent in Costa Rica does make some difference independently (when only permanent residents are taken into account); however, this difference is not significant for local involvement in Costa Rica. In addition, some differences in scores were found related to the motivations for why respondents moved to another country; however, this also corresponds with the permanent $v$ s. temporary resident difference (negative push factors are often mentioned by permanent residents), and independently of that, the scores are not significant.

43. INEC census 2011. Available online: http://www.inec.go.cr/Web/Home/GeneradorPagina.aspx (accessed on 1 July 2012).

44. Baumeister, E.; Fernández, E.; Acuña, G. Estudios sobre las migraciones regionales de los Nicaragüenses (in Spanish); Editorial de Ciencias Sociales: Guatemala City, Guatemala, 2008.

45. Hogenstijn, M.; Van Middelkoop, D. 'Zo werkt dat hier niet'. Gevestigden en buitenstaanders in nieuwe sociale en ruimtelijke kaders (in Dutch). $\mathrm{PhD}$ Thesis, Utrecht University, Utrecht, The Netherlands, 2008.

46. Portes, A. Migration and development: Reconciling opposite views. Ethnic Racial Stud. 2009, 32, $5-22$.

(C) 2013 by the authors; licensee MDPI, Basel, Switzerland. This article is an open access article distributed under the terms and conditions of the Creative Commons Attribution license (http://creativecommons.org/licenses/by/3.0/). 